\title{
Analisis Kesalahan Siswa dalam Menyelesaikan Soal Cerita Siswa Kelas X IPS
}

\author{
Jefriza $^{1^{*}}$, Zulfitri Aima ${ }^{2}$, Lita Lovia ${ }^{3}$ \\ ${ }_{1,2,3}$ STKIP PGRI Sumatera Barat, Padang, Indonesia \\ ${ }^{*}$ Corresponding Author
}

\begin{tabular}{l} 
Informasi Artikel \\
\hline DiterimaRedaksi: 02 Juli 2021 \\
RevisiAkhir: 12 November 2021 \\
DiterbitkanOnline: 31 Desember 2021 \\
Kata Kunci \\
\hline Analisis Kesalahan, soal cerita, \\
prosedur Newman \\
Korespondensi \\
\hline E-mail: rizajef138@gmail.com
\end{tabular}

\begin{abstract}
A B S T R A C T
This research is motivated by the many mistakes made by students in solving story problems. The purpose of this study was to find out the mistakes made by students in solving story problems on Trigonometry material and to find out the causes of errors made by students in working on story problems on Trigonometry material. This research method uses a descriptive method with a qualitative approach. The subjects of this study were students of class X IPS SMA PGRI 3 Padang in the 2020/2021 academic year who had been selected by total sampling. Instruments used for data collection in the form of tests, interviews, and documentation. The test results were analyzed based on the error according to Newman. The results showed that some students made mistakes in understanding, errors in transforming, errors in processing skills, errors in writing the final answer. The cause of this error is that students do not know what is actually being asked in the problem, and accidentally get information on the question, so they cannot complete the information for the next step, do not understand how it turns into a question. mathematical models, and not proficient in counting.
\end{abstract}

Penelitian ini dilatarbelakangi dengan banyaknya kesalahan yang dilakukan peserta didik dalam menyelesaikan soal cerita. Tujuan penelitian ini untuk mengetahui kesalahan yang dilakukan siswa dalam menyelesaikan soal cerita pada materi Trigonometri dan mengetahui penyebab terjadinya kesalahan yang dilakukan oleh siswa dalam mengerjakan soal cerita pada materi Trigonometri. Metode penelitian ini menggunakan metode deskriptif dengan pendekatan kualitatif. Subjek penelitian ini siswa kelas X IPS SMA PGRI 3 Padang Tahun Ajaran 2020/2021 yang telah dipilih secara total sampling. Instrument yang digunakan untuk pengumpulan data berupa tes, wawancara, dan dokumentasi. Hasil tes dianalisis berdasarkan kesalahan menurut Newman. Hasil penelitian menunjukkan sebagian siswa melakukan kesalahan dalam memahami, kesalahan dalam mentransformasi, kesalahan dalam keterampilan proses kesalahan penulisan jawaban akhir. Penyebab kesalahan ini adalah siswa tidak mengetahui apa yang sebenarnya ditanyakan dalam soal, dan tidak sengaja mendapatkan informasi pada soal tersebut, sehingga mereka tidak dapat melengkapi informasi untuk langkah selanjutnya, tidak mengerti bagaimana menjelma menjadi sebuah pertanyaan. model matematika, dan tidak mahir dalam menghitung.

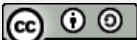

02021 by the authors. Submitted for possible open access publication under the terms and conditions of the Creative Commons Attribution-ShareAlike 4.0 International License-(CC-BY-SA) (https://creativecommons.org/licenses/by-sa/4.0/)

\section{Pendahuluan}

Pembelajaran matematika sendiri memiliki manfaat yang penting dalam kehidupan sehari-hari, namun sebagian besar siswa beranggapan bahwa matematika merupakan mata pelajaran yang sulit dipelajari, sehingga daya tarik matematika bagi siswa pada umumnya rendah. Selain itu, dalam proses pembelajaran matematika, guru dihadapkan dengan banyak karakteristik siswa yang beragam, dan banyak siswa yang mengalami kesulitan dalam memahami materi bahkan memecahkan masalah matematika dalam proses pembelajaran. Perlu ditingkatkan yaitu dalam proses pembelajaran matematika masalah ketelitian, keterampilan dan penguasaan siswa tidak hanya harus menggunakan contoh soal yang diberikan oleh guru, tetapi juga mengerjakan soal lain yang berbeda, agar siswa lebih memahami, sehingga agar siswa tidak mengalami kesulitan tersebut.

Pendidikan merupakan bagian penting dalam menumbuhkan bakat-bakat yang luar biasa. Selain itu, pendidikan juga dapat mengembangkan potensi dirinya. Pendidikan adalah proses 
belajar untuk memperoleh pengetahuan, mengembangkan sikap dan keterampilan sikap. Pendidikan matematika memegang peranan yang sangat penting, karena matematika merupakan ilmu dasar yang dapat diterapkan pada semua bidang kehidupan [4]. Matematika merupakan ilmu dasar yang perlu dipelajari di semua jenjang mulai dari sekolah dasar hingga perguruan tinggi. Namun, saat ini matematika merupakan mata pelajaran yang kurang diminati oleh siswa, karena matematika masih dianggap sebagai mata pelajaran yang sangat sulit dan membingungkan. Salah satu materi yang tidak disukai siswa adalah trigonometri. Buku ajar trigonometri merupakan salah satu buku ajar yang harus dikuasai oleh siswa kelas $\mathrm{X}$ matematika pada semester genap

Pendidikan merupakan bagian yang sangat penting dalam membentuk manusia yang lebih unggul. Selain itu pendidikan juga mampu mengembangkan potensi yang ada didalam dirinya. Pendidikan adalah proses suatu pembelajaran untuk memperoleh pengetahuan, pengembangan sikap, dan keterampilan sikap. Pendidikan Matematika memiliki peran yang sangat penting karena matematika adalah ilmu dasar yang dapat digunakan dalam berbagai bidang kehidupan [4]. Matematika merupakan ilmu dasar yang dipelajari oleh semua jenjang, dari jenjang Sekolah Dasar hingga Perguruan Tinggi. Namun saat ini matematika merupakan mata pelajaran yang kurang diminati oleh peserta didik, karena matematika masih dianggap pelajaran yang sangat menyulitkan dan membingungkan. Salah satu materi yang kurang disukai peserta didik adalah materi Trigonometri. Materi Trigonometri merupakan salah satu materi pada mata pelajaran matematika kelas X semester genap, Siswa harus menguasainya dengan baik. Trigonometri adalah ilmu yang mempelajari hubungan antara panjang dan sudut suatu segitiga. Biasanya materi trigonometri semacam ini diajarkan setelah siswa menerima materi Pythagoras.

Berdasarkan hasil observasi dan wawancara sederhana dan terbatas dengan Aulia, guru matematika kelas X di SMA PGRI 3 Padang, didapatkan kesan bahwa siswa masih mengalami kesulitan dalam menyelesaikan soal trigonometri terutama pada sub bab relasional. Sudut, aturan sinus dan kosinus, pertanyaan dan pertanyaan cerita. Berbeda dengan contoh. Dalam proses pembelajaran, hanya beberapa siswa yang berinisiatif bertanya, dan selebihnya hanya mencatat, mendengarkan pelajaran, dan mengerjakan latihan yang diberikan oleh guru. Setiap tahun, rata-rata ulangan harian siswa masih lebih rendah dari KKM. Terlihat dari rata-rata masih banyak siswa yang mengalami kesulitan dalam menyelesaikan soal trigonometri terutama pada tahap memahami soal dan tahap menghitung.

Menurut [8], setiap peserta didik yang berprestasi dalam belajar biasanya memiliki kreativitas. Salah satu faktor yang dianggap menjadi penyebab dari rendahnya prestasi belajar peserta didik adalah kesalahan dalam menyelesaikan soal. Kesalahan yang dilakukan peserta didik dalam penyelesaian soal perlu diidentifikasi. Menurut penelitian sebelumnya yang dilakukan oleh [17] pada judul "Analisis Kesalahan Peserta Didik dalam menyelesaikan Soal Cerita Matematika" menyatakan bahwa untuk meningkatkan hasil belajar matematika maka sumber kesalahan yang dilakukan oleh peserta didik harus segera diatasi karena peserta didik akan selalu mengalami kesulitan jika kesalahan sebelumnya tidak diperbaiki, terutama soal yang memiliki karakteristik sama dari yang sebelumnya. Kesalahan-kesalahan Peserta didik dalam menyelesaikan soal trigonometri belum pasti diketahui letak kesalahannya. Dengan dilakukannya analisis kesalahan, diharapkan peserta didik dapat meminimalisir kesalahankesalahan dalam menyelesaikan soal trigonometri, sehingga dapat meningkatkan prestasi belajar.

Pada penelitian ini, metode analisis yang akan digunakan adalah metode analisis kesalahan Newman. Metode analisis kesalahan Newman ini diperkenalkann pertama kali pada tahun 1977 oleh Anne Newman, seorang guru mata pelajaran matematika di Australia [1]. Pada metode ini, untuk membantu menemukan kesalahan pada peserta didik ketika menyelesaikan 
soal berbentuk uraian. Newman menyarankan lima aspek yaitu, (1) tahapan membaca (reading), (2) tahapan memahami (comprehension) makna suatu permasalahan, (3) tahapan transformasi (transformation), (4) tahapan keterampilan proses (process skill), dan (5) tahapan penulisan jawaban (endcoding).

Oleh karena itu, Peneliti berharap penelitian ini dapat mendeskripsikan kesalahan yang dilakukan siswa dalam menyelesaikan masalah cerita berdasarkan langkah-langkah prosedur Newman, sehingga pendidik dapat menemukan solusi yang tepat untuk mengatasi kesalahan yang dilakukan siswa, sehingga dapat memaksimalkan proses pembelajaran.

\section{Metode Penelitian}

Menurut [11] dalam pendekatan kualitatif data yang dikumpulkan bukan berupa angkaangka, melainkan data tersebut berasal dari naskah wawancara, catatan lapangan, dokumen pribadi, catatan, memo, dan dokumen resmi lainnya. Sedangkan menurut Creswell dan Clark [10] menjelaskan bahwa proses penelitian kualitatif ini melibatkan upaya-upaya penting, seperti mengajukan pertanyaan-pertanyaan dan prosedur-prosedur, mengumpulkan data yang spesifik dari partisipan, dan menganalisis data secara induktif. Berdasarkan beberapa pengertian di atas dapat diartikan bahwa penelitian kualitatif adalah menyusun suatu pernyataan penelitian yang menghasilkan data deskriptif berbentuk lisan atau kata-kata tertulis. Pendekatan pada penelitian ini menggunakan pendekatan kualitatif dengan jenis deskriptif. Menurut [2], penelitian deskriptif adalah penelitian yang digunakan untuk mendeskripsikan dan menjawab persoalan-persoalan suatu fenomena atau peristiwa yang terjadi saat ini, baik tentang fenomena dalam variabel tunggal maupun korelasi dan atau perbandingan berbagai variabel. Penelitian deskriptif merupakan penelitian yang mendeskripsikan suatu peristiwa atau kejadian yang menjadi pusat perhatian tanpa memberikan perlakuan, manipulasi, atau perubahan pada variabel yang diteliti, dan menggambarkan suatu kondisi yang apa adanya. Tujuan penelitian deskriptif yaitu untuk memaparkan secara sistematis, akurat, dan faktual tentang karakteristik yanng sangat luas dari suatu populasi. Berdasarkan pengertian dan tujuan dari penelitian deskriptif diatas adalah sesuai yang akan peneliti lakukan. Penelitian ini berusaha memaparkan macam-macam kesalahan yang dialami oleh siswa kelas X SMA PGRI 3 Padang dalam menyelesaikan soal materi trigonometri.

\section{Hasil dan Pembahasan}

Berdasarkan hasil penelitian yang telah dilaksanakan di SMA PGRI 3 Padang kelas X tahun pelajaran 2020/2021 pada materi Trigonomeri. Penelitian ini mengambil data dengan diawali memberikan tes kepada 24 peserta didik yang berjumlah 5 soal sudah melalui proses validasi dan dilaksanakan dalam waktu 90 menit. Pada saat tes dilaksanakan yang memberikan hasil jawaban hanya 20 peserta didik dan 3 peserta didik tidak mengumpulkan hasil jawaban tes karena 2 peserta didik sakit dan 1 peserta didik alfa, namun hal ini tidak mengganggu dalam proses ketahap selanjutnya. Sebelum tes dilaksanakan, terlebih dahulu peserta didik diminta untuk mencermati petunjuk pengerjaan soal yang berada di bagian atas soal. Setelah peneliti mendapatkan data hasil tes peserta didik, selanjutnya peneliti menentukan subjek penelitian sebanyak 5 peserta didik dengan ketentuan 1 subjek dengan kemampuan tinggi, 2 subjek dengan kemampuan sedang dan 2 subjek dengan kemampuan rendah. Setelah itu, peneliti mengidentifikasi jenis kesalahan-kesalahan apa saja yang dilakukan oleh ke 5 subjek tersebut 
dengan menggunakan analisis menurut Prosedur Newman. Dengan pengambilan subjek menggunakan total sampling diambil 5 subjek peserta didik, selanjutnya untuk dilakukan wawancara terkait jawabannya.

Berdasarkan hasil tes yang telah dilakukan peserta didik, menurut [3], untuk menentukan kedudukan tinggi, sedang dan rendah menggunakan nilai rata-rata, standar deviasi dan didapat hasil yaitu, sebjek dengan kemampuan rendah dimulai dari interval 0 sampai 58 , subjek dengan kemampuan sedang dimulai dari interval 59 sampai 85 dan subjek dengan kemampuan tinggi dimulai dari interval 86 sampai 100. Selanjutnya, peneliti akan memilih 5 peserta didik dari 10 peserta didik yang akan dijadikan subjek penelitian dari kategori rendah, sedang dan tinggi. Dapat dilihat dari tabel 1.

Tabel 1. Sampel Subjek Penelitian

\begin{tabular}{ccl}
\hline No & Kode Subjek & \multicolumn{1}{c}{ Nama Subjek } \\
\hline $\mathbf{1}$ & PD -05 & Ana Putri Ramadhani \\
$\mathbf{2}$ & PD -11 & Jerry Pratama Putra \\
$\mathbf{3}$ & $\mathrm{PD}-02$ & Amanda Cania Puja \\
$\mathbf{4}$ & $\mathrm{PD}-07$ & Dafa Febrio \\
$\mathbf{5}$ & $\mathrm{PD}-20$ & Sherly Sri Damai Rejeki \\
\hline
\end{tabular}

Setelah menganalisis jawaban subjek penelitian, terdapat banyak kesalahan yang peserta didik lakukan. Berikut jenis kesalahan yang dilakukan peserta didik dalam menyelesaikan tes uraian matematika. Terlihat dari tabel 2.

Tabel 2. Jenis- Jenis Kesalahan Peserta Didik

\begin{tabular}{cccc}
\hline Kode & \multicolumn{3}{c}{ Jenis Kesalahan } \\
\cline { 2 - 4 } Peserta & Soal Nomor 1 & Soal Nomor 2 & Soal Nomor 3 \\
Didik & W, X & V, W, X & V, W, X \\
PD - 02 & V, W, X & V, W, X & Z \\
PD - 03 & X & W, X & Z \\
PD - 04 & U, V, W, X & U, V, W, X & U, V, W, X \\
PD - 05 & T, U, V, W, X & T, U, V, W, X & T, U, V, W, X \\
PD - 06 & W, X & V, W, X & W, X \\
PD - 07 & U, X & U, W, X & U, W, X \\
PD - 08 & U, X & Z & Z \\
PD - 09 & U, X & Z & Z \\
PD - 11 & V, W, X & Z & Z \\
PD - 12 & U, V, W, X & T, U, V, W, X & Z \\
PD - 13 & W, X & V, W, X & V, W, X \\
PD - 14 & V, W, X & V, W, X & Z \\
PD - 15 & W, X & V, W, X & Z \\
PD - 16 & V, W, X & Z & Z \\
PD - 17 & X & W, X & W, X \\
PD - 18 & U, V & U, V, W, X & Z \\
PD - 19 & X & X & W, X \\
PD - 20 & U, V, W, X & U, V, W, X & U, V, W, X \\
PD - 22 & & & \\
\hline
\end{tabular}


Keterangan :

$\mathrm{T}$ : Kesalahan membaca

$\mathrm{U}:$ Kesalahan pemahaman

V: Kesalahan transformasi

W: Kesalahan proses penyelesaian

$\mathrm{X}$ : Kesalahan penulisan jawaban

$\mathrm{Z}$ : Soal tidak dikerjakan

Dengan melihat data kesalahan masing-masing siswa pada Tabel 2, terlihat bahwa dalam menyelesaikan soal cerita trigonometri siswa masih banyak melakukan kesalahan berdasarkan program kesalahan Newman. Berikut adalah ringkasan dari banyaknya siswa yang melakukan kesalahan, seperti yang ditunjukkan pada Tabel 3.

Tabel 3. Rekapitulasi Banyak Kesalahan Siswa

\begin{tabular}{lcccc}
\hline \multirow{2}{*}{ Jenis Kesalahan } & \multicolumn{2}{c}{$\begin{array}{c}\text { Banyak Siswa Melakukan } \\
\text { Kesalahan pada Soal }\end{array}$} & \multirow{2}{*}{ Total } \\
\cline { 2 - 4 } & 1 & 2 & 3 & \\
\hline Membaca & 1 & 2 & 1 & 4 \\
Pemahaman & 8 & 6 & 4 & 18 \\
Transformasi & 9 & 11 & 5 & 25 \\
Keterampilan Proses & 12 & 14 & 9 & 35 \\
Penulisan Akhir & 18 & 15 & 9 & 42 \\
\hline
\end{tabular}

Pada Tabel 3 ini Terlihat banyaknya kesalahan yang ada pada kesalahan siswa terdapat pada penulisan akhir. Dilihat dari hasil telah diselesaikan siswa dalam menyelesaikan soal tersebut ditemukan siswa tidak membuat jawaban akhir sesuai dengan berdasarkan yang ditanyakan pada soal yang diberikan. Maka dapat diperoleh jenis - jenis kesalahan siswa dalam menyelesaikan soal cerita pada materi Trigonometri. Setelah mengetahui jenis kesalahan yang dilakukan siswa tersebut. Untuk membahas lebih detail maka perlu dibahas lebih lanjut tentang analisis kesalahan masing-masing siswa dalam menyelesaikan soal cerita pada materi trigonometri. Kesalahan yang ditemukan dalam penelitian ini adalah:

\subsection{Kesalahan dalam Membaca}

Kesalahan membaca adalah siswa yang kurang teliti dan kesalahan dalam memaknai dalam apa yang diminta pada soal "Alvin melihat puncak dengan sudut $45^{\circ}$ terhadap garis horizontal dari jarak 2m, tentukan tinggi pohon jika tinggi pohon Alvin diukur dari tanah adalah $1,6 \mathrm{~m}$ ? Namun, dari soal yang diberikan siswa tidak mampu untuk menyelesaikan kedalam bentuk penyelesaian berikutnya, yang terdapat pada proses penyelesaian peserta didik pada gambar 1.

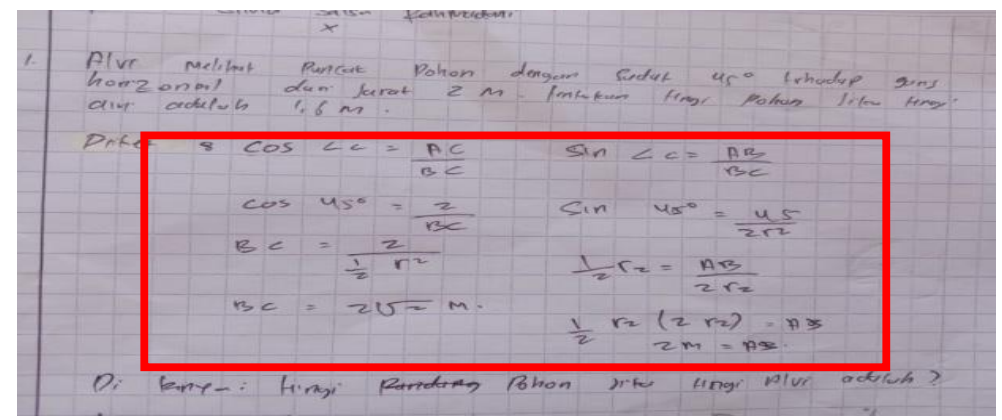

Gambar 1. Kesalahan Siswa dalam Membaca 
Gambar 1 menunjukkan bahwa siswa melakukan kesalahan saat membaca soal. Peserta didik dapat membaca soal tetapi tidak bisa memahami masalah, terlihat dari tulisan jawaban yang mengenai hal apa yang diketahui namun tidak dituliskan hal apa yang ditanyakan. Pada tahap mentranformasikan masalah sudah benar terlihat pada peserta didik dapat menentukan rangkaian operasi atau metode untuk menyelesaikan permasalahan soal dengan tepat, akan tetapi pada tahap keterampilan proses melakukan kesalahan terlihat pada peserta didik mengalami kesalahan dalam menyelesaikan masalah akibatnya pada tahap penulisan jawaban dipastikan salah. [16] mengemukakan bahwa bentuk salah yang terdapat pada kesalahan membaca adalah fenomena menghasilkan kata atau simbol pada objek yang dianggap salah dan dikenali oleh objek tersebut. Salah menjelaskan simbol dalam masalah dan langkah-langkah untuk menyelesaikan masalahyang masih kurang tepat.

\subsection{Kesalahan dalam Memahami}

Kesalahan dalam memahami hal ini adalah siswa tidak tahu persisapan yang harus ditanyakan pada soal, dan siswa tidak bisa mendapatkan informasi yang terdapat pada soal yang diberikan seperti "Alvin melihat puncak dengan sudut $45^{\circ}$ terhadap garis horizontal dari jarak $2 \mathrm{~m}$, tentukan tinggi pohon jika tinggi pohon Alvin diukur dari tanah adalah 1,6m?" maka peserta didik tidak bisa menyelesaikan soal dalam bentuk solusi penyelesaian.

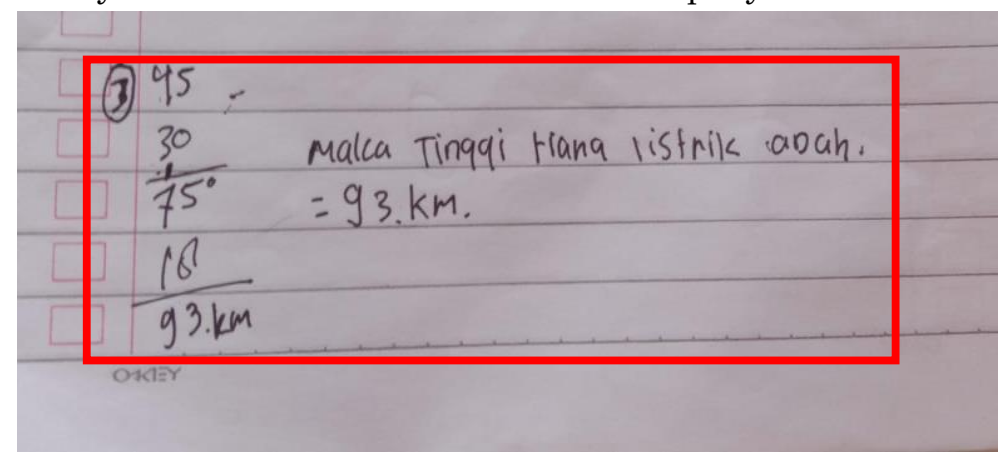

Gambar 2. Kesalahan dalam Memahami

Gambar 2 menunjukkan bahwa peserta didik melakukan kesalahan dalam memahami bentuk soal. Berdasarkan bentuk hasil yang diperoleh dalam jawaban, Pada peserta didik dapat membaca soal namun melakukan kesalahan pada tahap memahami masalah, terlihat bahwa siswa siswa masih belum memahami apa yang seharusnya diketahui dalam soal, dan informasi tersebut diperoleh secara tidak sengaja, karena siswa hanya menjumlahkan nilai sudut atau semua nilai yang terdapat dalam soal. pertanyaan. Menurut [14], siswa melakukan kesalahan dalam memahami, berupa tidak menuliskan informasi dan pertanyaan yang diajukan. Karena siswa kurang memahami soal atau tujuan soal yang dikirimkan kepada siswa tersebut, beberapa jawaban siswa tidak lengkap.

\subsection{Kesalahan Transformasi}

Pada soal berikut ini "Alvin melihat puncak dengan sudut $45^{\circ}$ terhadap garis horizontal dari jarak $2 \mathrm{~m}$, tentukan tinggi pohon jika tinggi pohon Alvin diukur dari tanah adalah 1,6m?" ditemukan Kesalahan transformasi akan mempengaruhi kesalahan-kesalahan yang lainnya yaitu kesalahan keterampilan proses dan kesalahan penulisan jawaban. Siswa melakukan kesalahan dalam mengubah bentuk masalah saat menyelesaikan masalah cerita. Tidak dapat menentukan proses pemecahan masalah, terutama langkah-langkah pemecahan masalah. Dapat dilihat pada gambar 3 . 


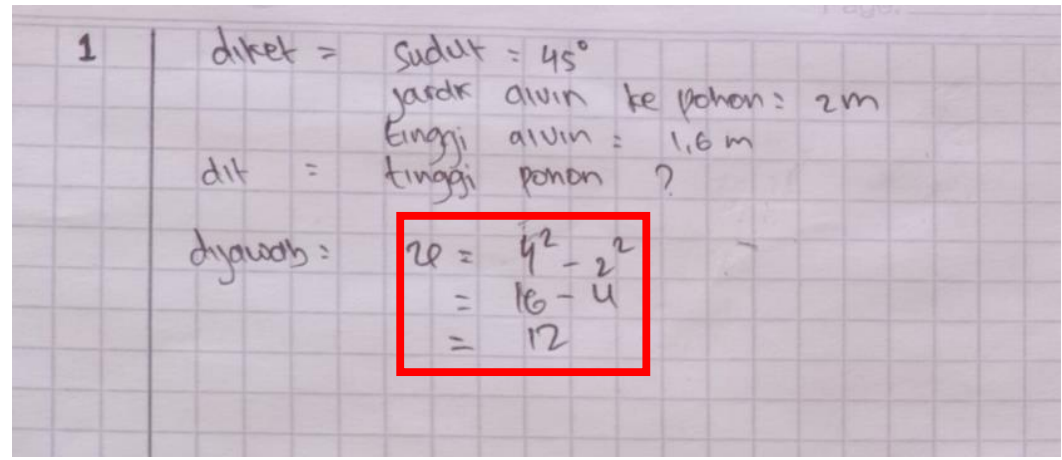

Gambar 3. Kesalahan Transformasi

Pada gambar 3 peserta didik mampu membacakan soal dan memahami masalah, terlihat dari peserta didik dapat menuliskan apa diketahui dan ditanya pada soal. Pada tahap transformasi, peserta didik mengalami kesalahan terlihat dari peserta didik tidak mampu menentukan metode atau rumus yang akan digunakan untuk menyelesaikan soal, akibatnya sudah dipastikan peserta didik melakukan kesalahan pada tahap keterampilan proses dan penulisan jawaban. Menurut [12], bentuk kesalahan yang ada pada siswa itu terjadi pada kesalahan mentransformasikan yang tidak mampu mengoperasikan sesuai dengan apa yang diminta pada soal.

\subsection{Kesalahan Keterampilan Proses}

Pada soal berikut ini "Seorang anak berada pada jarak 32 meter dari kaki sebuah gedung. Ia mengamari dari puncak gedung dengan helikopter diatasnya dengan sudut elevasi masing masing $30^{\circ}$ dan $45^{\circ}$. Hitunglah tinggi helikopter tersebut dari atas gedung?" ditemukan Kesalahan dalam keterampilan proses ini dapat dilihat dari kesalahan dalam menentukan operasi serta kesalahan dalam komputasi pada penyelesaian soal yang mereka buat. Akan tetapi siswa mampu dalam menentukan bentuk Operasi aritmatika yang ada dalam soal tetapi tidak sesuai dengan langkah penyelesaian.

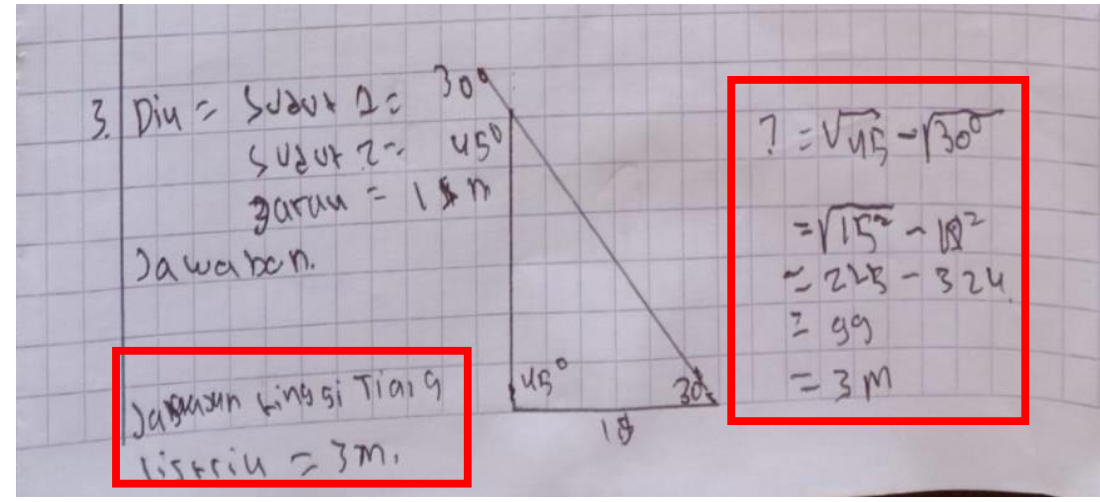

Gambar 4. Kesalahan Keterampilan Proses

Pada gambar 4 peserta didik mampu membacakan soal dan memahami masalah, terlihat dari peserta didik tidak dapat menuliskan apa yang diketahui dan ditanyakan pada soal. Pada tahap transformasi, peserta didik juga tidak mampu menuliskan metode penyelesaian yang akan digunakan untuk menyelesaikan soal. Tetapi pada tahap keterampilan proses peserta didik juga mengalami kesalahan terlihat dari peserta didik tidak mampu menyelesaikannya dengan apa sesuai dengan apa yang diperlukan dalam soal dan juga salah menuliskan hasil nilai dari sudut- 
sudut elevasi yang ditanyakan akibatnya pada tahap penulisan jawaban sudah dipastikan peserta didik mengalami kesalahan. [9] menyatakan bahwa bentuk kesalahan keterampilan proses ialah tidak mampu membuat langkah-langkah yang dipergunakan dalam serangkaian bentuk operasi yang digunakan.

\subsection{Kesalahan Penulisan Jawaban Akhir}

Pada soal berikut ini "Seorang anak berada pada jarak 32 meter dari kaki sebuah gedung. Ia mengamari dari puncak gedung dengan helikopter diatasnya dengan sudut elevasi masingmasing $30^{\circ}$ dan $45^{\circ}$. Hitunglah tinggi helikopter tersebut dari atas gedung?" Ditemukan kesalahan penulisan jawaban akhir ini banyak siswa yang tidak mampu menemukan hasil akhir dari soal dengan benar, serta siswa tidak mampu menunjukkan jawaban akhir dengan benar sesuai dengan kesimpulan. Dapat dilihat dengan rinci pada gambar 5 dibawah ini.

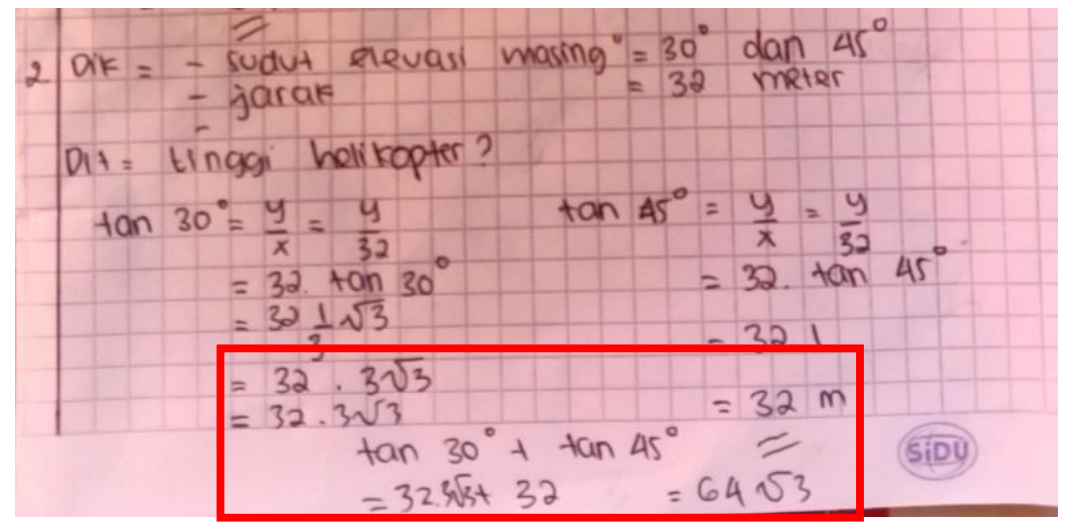

Gambar 5. Kesalahan Penulisan Jawaban Akhir

Pada gambar 5 peserta didik mampu membacakan soal dan memahami masalah terlihat dari peserta didik mampu menuliskan apa yang diketahui dan ditanyakan. Pada tahap transformasi, peserta didik juga mampu menentukan rumus yang akan digunakan untuk menyelesaikan soal. Selanjutnya pada tahap keterampilan proses, peserta didik juga mampu menjalankan dan menghitung operasi matematika yang digunakan dengan tepat dan benar. Pada tahap terakhir yaitu tahap penulisan jawaban, peserta didik kurang mampu menuliskan hasil jawaban sesuai dengan apa yang ditanyakan pada soal. Menurut [15], bentuk kesalahan dalam penulisan jawaban akhir ini telah berhasil pada tahap pengolahan data tetapi gagal dalam menuliskan solusi dari kesimpulan yang ada pada soal namun pada tahap akhir ini banyak siswa melakukan kesalahan dalam menyelesaikan jawaban akhir yang diperoleh oleh siswa itu sendiri.

\section{Kesimpulan}

Kesalahan yang di dapatkan berdasarkan pada 5 subjek kelas X IPS antara lain kesalahan membaca (reading), kesalahan memahami (Comprehension error), kesalahan dalam mentransformasi (transformation error), kesalahan keterampilan proses (processing error), kesalahan penulisan jawaban akhir (encoding). Kesalahan dalam memahami hal ini adalah siswa tidak tahu persisapan yang harus ditanyakan pada soal, dan siswa tidak bisa mendapatkan informasi yang terdapat pada soal yang diberikan, sehingga tidak bisa menyelesaikan soal dalam bentuk solusi. Kesalahan konversiakan mempengaruhi kesalahan lainnya, yaitu kesalahan keterampilan penanganan dan kesalahan penulisan jawaban. Kesalahan siswa dalam mentransformasikan bentuk masalah menjadi pemecahan masalah 
cerita. Saat menggunakan tanda operasi aritmatika dalam soal yang diberikan masih tidak dapat mengubah soal menjadi model matematika dengan benar atau salah.

Kesalahan ini terjadi karena siswa tidak dapat mengubah tabel ke model matematika dan tidak memahami cara menyelesaikan masalah. Kesalahan keterampilan proses adalah kesalahan yang terjadi karena siswa tidak dapat mengubah formulir perhitungan dengan benar. Dan kurang mengerti dalam menghitung secara akurat. Kesalahan dalam menulis jawaban akhir adalah kesalahan yang terjadi karena siswa kurang terampil atau tidak mampu menulis jawaban akhir soal. Alasan kesalahan ini adalah siswa tidak memahami isi yang akan ditanyakan dan tidak dapat memperoleh informasi yang benar tentang pertanyaan yang diajukan. Oleh karena itu, siswa tersebut masih belum mampu menyelesaikan masalah dan kurang pandai dalam menyusun model matematika dalam perhitungan.

\section{Daftar Pustaka}

[1] Alamsyah, I. (2020). Analisis Kesalahan Dalam Menyelesaikan Soal Cerita Ditinjau Dari Kemampuan Pemecahan Masalah Berdasarkan Prosedur Newman (Doctoral dissertation, Universitas Pancasakti Tegal).

[2] Arifin, Zainal. 2012. Penelitian Pendidikan Metode Dan Paradigma Baru. Bandung: Rosdakarya

[3] Arikunto, S. 2016. Dasar Dasar Evaluasi Pendidikan Edisi Kedua. Jakarta: PT Bumi Aksara.

[4] Badaruddin, dkk. 2016. "Analisis Kesalahan dalam Menyelesaikan Soal-Soal Operasi Hitung Pecahan pada Siswa Kelas VII SMP Negri 10 Kendari”. Jurnal Penelitian Pendidikan Matematika Volume 4 No. $2,44$.

[5] Felayani, Meirita Rahma. 2013. Pembentukan Karakter Dan Pemecahan Masalah Melalui Model Probing Prompting Berbantuan Scaffolding Materi Baris Dan Deret Kelas XI SMK. Skripsi: UNNES

[6] Gaya, Dari, and Kognitif Mahasiswa. 2017. "Analisis Kesalahan Berdasarkan.” Aksioma 8(1): $17-30$

[7] Hartini. 2008. Analisis Kesalahan Siswa Menyelesaikan Soal Cerita pada Kompetensi Dasar Menemukan Sifat dan Menghitung Besaran-Besaran Segi Empat Siswa Kelas VII Semester II SMP Nur Hidayah Surakarta Tahun Pelajaran 2006/ 2007. UNS: Tesis.

[8] Isnani, Waluya, S. B., Rochmad, Wardono. (2020, April). Analysis of mathematical creativity in mathematics learning is open ended. In Journal of Physics: Conference Series, (Vol. 1511, No. 1, p. 012102).

[9] Jha, Shio Kumar. 2012. "Mathematics Performance of Primary School Students in Assam (India): An Analysis Using Newman Procedure." International Journal of Computer Applications in in Engineering Sciences II(I): 17-21.

[10] Lestari, T. 2015. Kumpulan Teori untuk Kajian Pustaka Penelitian Kesehatan. Yogyakarta: Nuha Medika.

[11] Moleong, L.J. 2004. Metodologi Penelitian Kualitatif. Bandung: PT Remaja.

[12] Praktitipong, Natcha, and Satoshi Nakamura. 2006. "Analysis of Mathematics Performance of Grade Five Students in Thailand Using Newman Procedure." Journal of International Cooperation in Education, 9(1): 111-12. 
[13] Rahardjo dan Astuti. 2011. Pembelajaran Soal Cerita Pada Operasi Hitung Campuran di SD. Yogyakarta: Pusat Pengembangan dan Pemberdayaan Pendidik dan Tenaga Kependidikan Matematika.

[14] Rr Chusnul, C., Mardiyana, and S. Dewi Retno. 2017. "Errors Analysis of Problem Solving Using the Newman Stage after Applying Cooperative Learning of TTW Type." AIP Conference Proceedings 1913(December).

[15] Santoso, D. A., A. Farid, and B. Ulum. 2017. "Error Analysis of Students Working about Word Problem of Linear Program with NEA Procedure." Journal of Physics: Conference Series 855(1).

[16] Singh, Parmjit, Arba Abdul Rahman, and Teoh Sian Hoon. 2010. "The Newman Procedure for Analyzing Primary Four Pupils Errors on Written Mathematical Tasks: A Malaysian Perspective." Procedia - Social and Behavioral Sciences 8(5): 264-71. http://dx.doi.org/10.1016/j.sbspro.2010.12.036.

[17] Yuliyanti, E. (2020). Analisis Kesalahan Peserta Didik Dalam Menyelesaikan Soal Cerita Matematika (Studi Penelitian pada Peserta Didik Kelas X SMK Muhammadiyah Kramat Semester Ganjil Tahun Ajaran 2019/2020)(Doctoral dissertation, Universitas Pancasakti Tegal). 